\title{
Tattoo-Associated Viral Infections: A Review
}

\author{
Philip R Cohen ${ }^{1,2}$ \\ 'Department of Dermatology, University \\ of California, Davis Medical Center, \\ Sacramento, CA, USA; ${ }^{2}$ Department of \\ Dermatology, Touro University California \\ College of Osteopathic Medicine, Vallejo, \\ CA, USA
}

\begin{abstract}
Tattoos, a decorative form of body art, are produced by inoculating pigment into the dermis. Tattoo-associated viral infections can be cutaneous and localized to the tattoo ink; however, viral pathogens acquired during inoculation can cause systemic disease. A comprehensive review of the literature only reveals a limited number of published reports regarding patients with tattoo-associated cutaneous viral lesions. Cutaneous viral pathogens causing lesions to occur on a tattoo include herpes simplex virus (HSV), human papillomavirus (HPV), molluscum contagiosum, rubella, and vaccinia. HPV lesions (45 patients) and molluscum contagiosum (14 patients) are the most frequently reported tattoo-associated viral lesions; nearly all the patients were immunocompetent. HPV lesions included verruca vulgaris (29 patients), verruca plana (14 patients) and human immunodeficiency virus (HIV)associated acquired epidermodysplasia verruciformis (two men). Hypotheses for tattooassociated HPV lesions and molluscum contagiosum include a black ink-induced cutaneous immunocompromised district since the viral lesions all occurred in black or dark ink and the use of virus-contaminated instruments, pigment, or both during tattoo inoculation. Other sources of HPV include viral spread from a wart that is present but not associated with the tattoo site or virus transmission from the tattooist resulting from contact with a wart on an ungloved hand or HPV-containing saliva used to thin the pigment. Herpes compunctorum (three patients), vaccinia (two patients), and rubella (one patient) were less commonly reported. Blood borne viral pathogens associated with systemic manifestations - such as hepatitis B, hepatitis C and HIV - have also been acquired during tattoo inoculation; however, health care interventions have been adopted to attempt prevention of viral agent transmission during tattoo acquisition.
\end{abstract}

Keywords: hepatitis, herpes simplex virus, human papillomavirus, molluscum contagiosum, tattoo, virus

\section{Introduction}

Tattooing produces a permanent design by inoculating exogenous pigment into the dermis. Dermatologic and systemic complications have been observed in patients who receive tattoos. ${ }^{1-35}$ In one series of 234 dermatology patients with tattoos, infection-either impetigo or warts-confined to the tattoo was observed in two $(0.9 \%)$ of the patients. ${ }^{3}$

Cutaneous viral infections at the site of tattoos have been observed. ${ }^{3,9-11,14-35}$ In addition, systemic viral infections may develop in individuals who acquire a tattoo. ${ }^{4-8,12,13}$ Viral infections associated with tattoos are reviewed.

\section{Materials and Methods}

The purpose of this paper is to provide a comprehensive traditional narrative review of viral infections that have been described to occur on tattoos. The PubMed
10991 Twinleaf Court, San Diego, CA

92131-3643, USA

Email mitehead@gmail.com 
archive of biomedical literature at the US National Institutes of Health's National Library of Medicine was used. Searches were performed of the following combination of terms, tattoo and German measles virus, hepatitis $\mathrm{B}$ virus, hepatitis $\mathrm{C}$ virus, herpew simplex virus, human immunodeficiency virus, human papillomavirus, molluscum contagiosum virus, rubella virus, smallpox virus, vaccinia virus, and warts.

The abstracts of the papers generated by each search were evaluated. For hepatitis B virus and hepatitis $C$ virus, seminal reviews were selected. For herpes simplex virus, human immunodeficiency virus, molluscum contagiosum virus, rubella (German measles) virus, and vaccinia (smallpox) virus, all the articles generated-and any relevant papers included in the reference section of the articles-were included in this paper. Tattoo-associated human papillomavirus infection had recently been summarized; in addition to that review article, papers describing the initial observations of patients with warts occurring on their tattoos and additional reported patients not presented in the review article are included in this paper.

Many of the articles cited in this paper were published in journals with limited, and often non-gratis, access. An effort has been made to summarize the salient features of the patients who were affected by tattoo-associated viral infections. This has been accomplished by providing succinct, yet extensively detailed, tables that present the characteristics of the individuals who were included in this paper.

\section{Discussion}

Individuals who have acquired tattoos can also develop cutaneous or systemic viral infections (Table 1). ${ }^{3-35}$ Herpes simplex virus (HSV), human papillomavirus (HPV), and molluscum contagiosum are common cutaneous viral infections associated with tattoos. Previously,

Table I Viral Infections and Tattoos

\begin{tabular}{|l|l|}
\hline Virus & Reference \\
\hline Hepatitis B virus & {$[4-6]$} \\
Hepatitis C virus & {$[4,6-8]$} \\
Herpes simplex virus & {$[9-11]$} \\
Human immunodeficiency virus & {$[4,12,13]$} \\
Human papillomavirus & {$[3,14,15,33-35]$} \\
Molluscum contagiosum virus & {$[16-29]$} \\
Rubella (German measles) virus & {$[30]$} \\
Vaccinia (smallpox) virus & {$[31,32]$} \\
\hline
\end{tabular}

albeit rare, rubella and vaccinia are skin-related viral infections that have also been observed on tattoos.

Systemic viral infections associated with the acquisition of tattoos include hepatitis and human immunodeficiency virus (HIV). Both hepatitis B and hepatitis $\mathrm{C}$ have been associated with tattooing. Indeed, there is a five to $30 \%$ risk of hepatitis $\mathrm{B}$ transmission and a three to $7 \%$ risk of hepatitis $\mathrm{C}$ transmission following a single needlestick injury from an infected individual. ${ }^{4}$

\section{Hepatitis B Infection}

Hepatitis B is a deoxyribonucleic acid (DNA) virus. Blood or sexual contact are the most common modes of transmission of hepatitis $\mathrm{B}$ infection. Acquisition of hepatitis $B$ infection results in acute infection that can potentially develop into a chronic infection; thereafter, some individuals develop liver cirrhosis or hepatocellular carcinoma or both. Indeed, in addition to needle stick injury and blood exposure (either through percutaneous or mucous membrane), tattooing (with unsterile needles) can also result in the transmission of hepatitis $B$ in recipients of tattoos. ${ }^{4-6}$

A comprehensive systematic review and meta-analysis found that individuals involved in high-risk behaviors demonstrate the strongest association between tattooing and risk of acquiring hepatitis B. These individuals include drug users, HIV positive persons, persons who acquire their tattoos with reused needles or in non-professional tattoo parlors, and street youth. However, hepatitis $\mathrm{B}$ transmission is also observed in individuals from the community (such as blood donors, pregnant women, and students), patients in the hospital, and prison inmates. ${ }^{4-6}$

Several interventions have been suggested to prevent hepatitis transmission from tattooing. First is universal hepatitis B immunization. Second is education of individuals likely to get tattoos-prisoners and young adults. And third, not only the development of safe tattoo programs in prisons but also enhanced regulation of tattoo parlors with regard to maintaining the appropriate guidelines for infection control. ${ }^{4-6}$

\section{Hepatitis C Infection}

Hepatitis $\mathrm{C}$ is a ribonucleic acid (RNA) virus. Recently acquiring a tattooing has been reported in $6 \%$ of patients with acute hepatitis $\mathrm{C}$ infection. However, if the tattoo was received at a professional tattoo parlor, definitive evidence of an increased risk of hepatitis $\mathrm{C}$ infection was not observed. ${ }^{4,6-8}$ 
However, hepatitis $\mathrm{C}$ transmission from tattoos is prevalent in persons who use intravenous drugs, prisoners, and veterans. Indeed, there is also an increased risk of hepatitis $\mathrm{C}$ virus transmission if a tattoo is applied by friends, acquired in prison using non-sterile equipment, or if the recipient belongs to a high-risk group. The latter include drug users, homeless individuals, patients who attend sexually transmitted disease clinics, and sex workers. ${ }^{4,6-8}$

Similar to hepatitis B, the use of sterile equipmentparticularly in prisons-should be encouraged to prevent hepatitis $\mathrm{C}$ virus transmission from tattooing. Also, youths should be educated to avoid receiving tattoos in potentially unsterile environments such as homes and prisons. Finally, educating and monitoring tattoo parlors for proper infection control measures is crucial. ${ }^{4,6-8}$

\section{Herpes Simplex Virus}

Herpes simplex virus-associated tattoo infection has only been, to the best of my knowledge, published in three individuals (Table 2) ${ }^{9-11}$ The first individual was reported by Marshall et al in 2007; the investigators coined the term "herpes compunctorum" to describe this phenomenon. ${ }^{9}$ Ten years later, Kluger and Armingaud reported the second patient; a year later, the third patient was described by Gerqari et al. ${ }^{10,11}$
The first patient with a tattoo-associated HSV infection was a 30-year-old man who had his tattoo at a commercial tattoo parlor. The procedure included single-use needles following an initial drawing of the tattoo lines and subsequent shading. His treatment required a seven-day hospitalization. The investigators concluded that this was a primary inoculation of herpes simplex virus infection; although they postulated that the needle had become contaminated with HSV during the tattooing, they could not definitively exclude the possibility that the damaged skin became superinfected with the virus after the procedure. ${ }^{9}$

The second patient with tattoo-associated HSV infection also had her tattooing done by a professional artist in a parlor. She was a healthy 31-year-old woman. Similar to the initial patient, the researchers concluded that this was a primary HSV infection. However, in contrast to the previous investigators, they favored the possibility of superinfection of the virus occurring on the fresh and healing wounded skin following tattooing in contrast to the viral infection being transmitted by the tattooist during the procedure or contamination of the needle or the ink. ${ }^{10}$

The third patient with tattoo-associated HSV infection was a 46-year-old woman who worked in the medical sector and had a toxic thyroid adenoma that was treated by lobectomy; she developed post-surgical

Table 2 Tattoo-Associated Herpes Compunctorum

\begin{tabular}{|c|c|c|c|c|c|c|}
\hline C & $\begin{array}{l}\text { Age } \\
\text { Sex }\end{array}$ & PCR & Path & AT & Comments & Ref \\
\hline I & $\begin{array}{l}30 y \\
M\end{array}$ & +HSV-I & $1^{\circ}$ & $\mathrm{F}$ & $\begin{array}{l}\text { Severe neuropathic pain, three days after extensive tattooing of the left arm. He had neither prior } \\
\text { HSV (oral or genital) infection nor complications after previous tattooing. He presented with a low } \\
\text { grade fever }\left(37.9^{\circ} \mathrm{C}\right) \text { and vesicles mainly in the shaded areas of the tattoo with minimal spread } \\
\text { outside the tattooed areas. HSV-I serology was positive for both lgM and lgG; lesion bacterial } \\
\text { culture also grew MSSA. }\end{array}$ & [9] \\
\hline 2 & $\begin{array}{l}31 y \\
W\end{array}$ & $\begin{array}{l}+H S V-I \\
\text {-VZV }\end{array}$ & $1^{\circ}$ & V & $\begin{array}{l}\text { Acute painful and itchy clustered and scattered pustules developed around a black tattoo on the } \\
\text { right flank three days after tattooing. She became febrile }\left(38.2^{\circ} \mathrm{C}\right) \text { and presented for treatment four } \\
\text { days later. Systemic antiviral and empiric antibacterial (cloxacillin, one gram twice daily) therapy, and } \\
\text { topical chlorhexidine was initiated; five days later, she had dry pustules, no fever, and no new } \\
\text { lesions. }\end{array}$ & {$[10]$} \\
\hline 3 & $\begin{array}{l}46 y \\
W\end{array}$ & NS & $2^{\circ}$ & A & $\begin{array}{l}\text { Vesicles developed at the sites of inking on both the upper and lower lips two days after tattooing; } \\
\text { fever and itching (that progressed to a burning sensation and pain) also developed. Her retro- } \\
\text { auricular lymph nodes also enlarged. By day four post-tattooing, she was receiving systemic and } \\
\text { topical antiviral therapy, and topical tetracycline ointment. After one week, there was complete } \\
\text { healing. }\end{array}$ & [II] \\
\hline
\end{tabular}

Abbreviations: A, acyclovir (800 mg TID, PO and topical ointment); AT, antiviral therapy; BID, twice daily; C, case; F, famciclovir (250 mg TID, PO); HSV-I, herpes simplex virus type I; M, man; mg, milligrams; MSSA, methicillin-sensitive Staphylococcus aureus; NS, not stated; Path, pathogenesis; PCR, polymerase chain reaction (of pustule or vesicular fluid); PO, orally; Ref, reference; TID, three times daily; V, valacyclovir (500 mg BID, PO); VZV, varicella-zoster virus; W, woman; y, years; $1^{\circ}$, primary infection via inoculation; $2^{\circ}$, secondary reactivation; +, positive; -, negative. 
hypothyroidism and received $75 \mathrm{mg}$ of levothyroxine daily. The cosmetic tattooing had been performed to outline her lips. She also had a prior history of herpes labialis; this was her second herpetic eruption of herpes labialis. ${ }^{11}$

\section{Human Immunodeficiency Virus (HIV) Infection}

Blood or body fluids or both can result in the transmission of HIV. The route of transmission is frequently through sexual intercourse; however, mother to baby transmission is also commonly observed. In addition, the use or abuse of drugs that are injected and acts of body adornment such as piercing and tattooing are skin breaching activities that allow direct inoculation of the virus. ${ }^{4,12,13}$

Yet, to the best of my knowledge, only three patients with tattoo-associated HIV infection have been reported (Table 3). ${ }^{12,13}$ Two were HIV-positive men who acquired their virus infection after being tattooed while incarcerated. The third was a woman who developed HIV infection following cosmetic tattooing of her lips, eyebrows and eyelashes. $^{12,13}$

The first patient was 22-years-old when he received a tattoo while in prison. The tattooing was performed with an unsterilized needle that had previously been used to tattoo other prisoners. His HIV infection was discovered 4 years later when he presented with thrombocytopenia. ${ }^{12}$

The second patient was a 31-year-old prisoner with a 14-month history of symptoms which were eventually diagnosed as HIV-associated myelopathy. Prior to arriving in prison he had sex with prostitutes and this may have also been an HIV-related risk factor. However, he received multiple tattoos in prison seven months before the onset of his symptoms and was aware that other prisoners had been tattooed with the same dirty needles. ${ }^{12}$

The third patient was a 30-year-old woman who was experiencing her fifth pregnancy; she terminated her first pregnancy, had two subsequent miscarriages, and finally a healthy boy. Her husband and six-year-old son were HIV-negative. Positive results of the HIV screening performed during her first antenatal visit prompted her physicians to establish the source of her infection. Although she had unprotected intercourse with a new partner two to 3 years prior to the pregnancy (during a temporary separation from her husband), the partner was tested and found to be HIV negative. Additional inquiry revealed a potential mode of HIV transmission-she had permanent makeup cosmetic tattooing in Vietnam at her home by a mobile beauty therapist 3 years earlier. The unregulated home tattoo industry had previously been recognized to have a high incidence of breaches in infection control. She subsequently decided to terminate the pregnancy. ${ }^{13}$

\section{Human Papillomavirus}

Dr. TC Fox, in a single paragraph accompanied by a handdrawn sketch, reported the first patient with verruca vulgaris on a tattoo in the Transactions of the New York Dermatological Society that were published in 1884 in the June and July issue (volume 2, page 216) of the Journal of Cutaneous and Venereol Diseases. He described a young man who had tattooed his forearm 5 years earlier;

Table 3 Tattoo-Associated Human Immunodeficiency Virus Infection

\begin{tabular}{|l|l|l|l|}
\hline Feature & Case I & Case 2 & Case 3 \\
\hline Age & 26-years-old & 30 -years-old & 3I-years-old \\
Sex & Man & Woman & Man \\
CC & Easy bruising & None & Ataxia, falling, hypoaesthesia, leg shaking and weakness \\
Dx & HIV-associated thrombocytopenia & Antenatal pregnancy screening & HIV-associated myelopathy \\
HIV Ab & + ELISA, + Western blot & + ELISA, + Western blot & + \\
\hline HIV RF & & & - \\
BT & - & - & - \\
HSA & - & - & - \\
IVDA & - & - & + \\
SWP & - & - &,+ in prison \\
Tattoo & + in prison & {$[13]$} & case 2 [12] \\
\hline Ref & case I [I2] & cosmetic at home & - \\
\hline
\end{tabular}

Abbreviations: Ab, antibody; BT, blood transfusion; CC, chief complaint, Dx, diagnosis, HIV, human immunodeficiency virus; HSA, homosexual activity; IVDA, intravenous drug abuse; Ref, reference; RF, risk factor; SWP, sex with prostitutes. 
about a year after tattoo placement, warts began to develop on the indigo lines of the tattoo. Indeed, 19 of the 20 warts occurred on the tattoo lines. ${ }^{33}$

Dr. HFB Walker, 24 years later, described the second patient with tattoo-associated warts. In a short communication published in October 10, 1908, issue (volume 2, page 1104) of the British Medical Journal, the infective warts of a young Englishman were reported. The publication included a figure that showed not only the position but also the relative size of the warts on the tattoo lines. He had neither current nor prior history of other warts. Six months earlier he had received a tattoo created with Indian ink by an Italian in Port Elizabeth, South Africa; a month later, the warts began to appear. There was one larger bleeding wart and the 37 smaller warts. ${ }^{34}$

Subsequently, more than 50 years after Dr. Walker published his patient, Captain Dale B. Watkins (who was working at the US Naval Hospital in Key West, Florida) reported another man whose tattoo had warts in a paper titled "Viral disease in tattoos: verruca vulgaris" that was included in the August 1961 issue of Archives in Dermatology (volume 84, pages 306-309). He described a 21-year-old man with a rose tattoo on his left arm that was received 2 years prior; soon after the application of the tattoo, biopsy-confirmed warts appeared. The man, who had no other verruca, presented with seven warts in the black pigment of the tattoo. Both the patient and his father were emotionally traumatized by the alteration of the tattoo at the biopsy site. The remaining warts were not treated since a course of management that was agreeable could not be established. ${ }^{35}$

Including these three men, tattoo-associated HPV infections have included not only verruca vulgaris (29 patients) (Figure 1) but also verruca plana (14 patients), and acquired epidermodysplasia verruciformis (two HIVpositive men) (Table 4); ${ }^{3,14,15}$ epidemiologic and clinical features were not completely described in all the individuals. HPV lesions on tattoos occurred three times more frequently in men $(75 \%, 21$ patients) as compared to women (25\%, 7 patients). Depending on the HPV lesion, the median onset age in both men and women was in their 30 s or 20 s. $^{15}$

Nearly all the patients were immunocompetent. Both men with HIV-associated acquired epidermodysplasia verruciformis were immunosuppressed because of their HIV infection. In addition, one of the men with verruca vulgaris was HIV positive. Several of the other patients with tattooassociated HPV lesions were not only tested for HIV
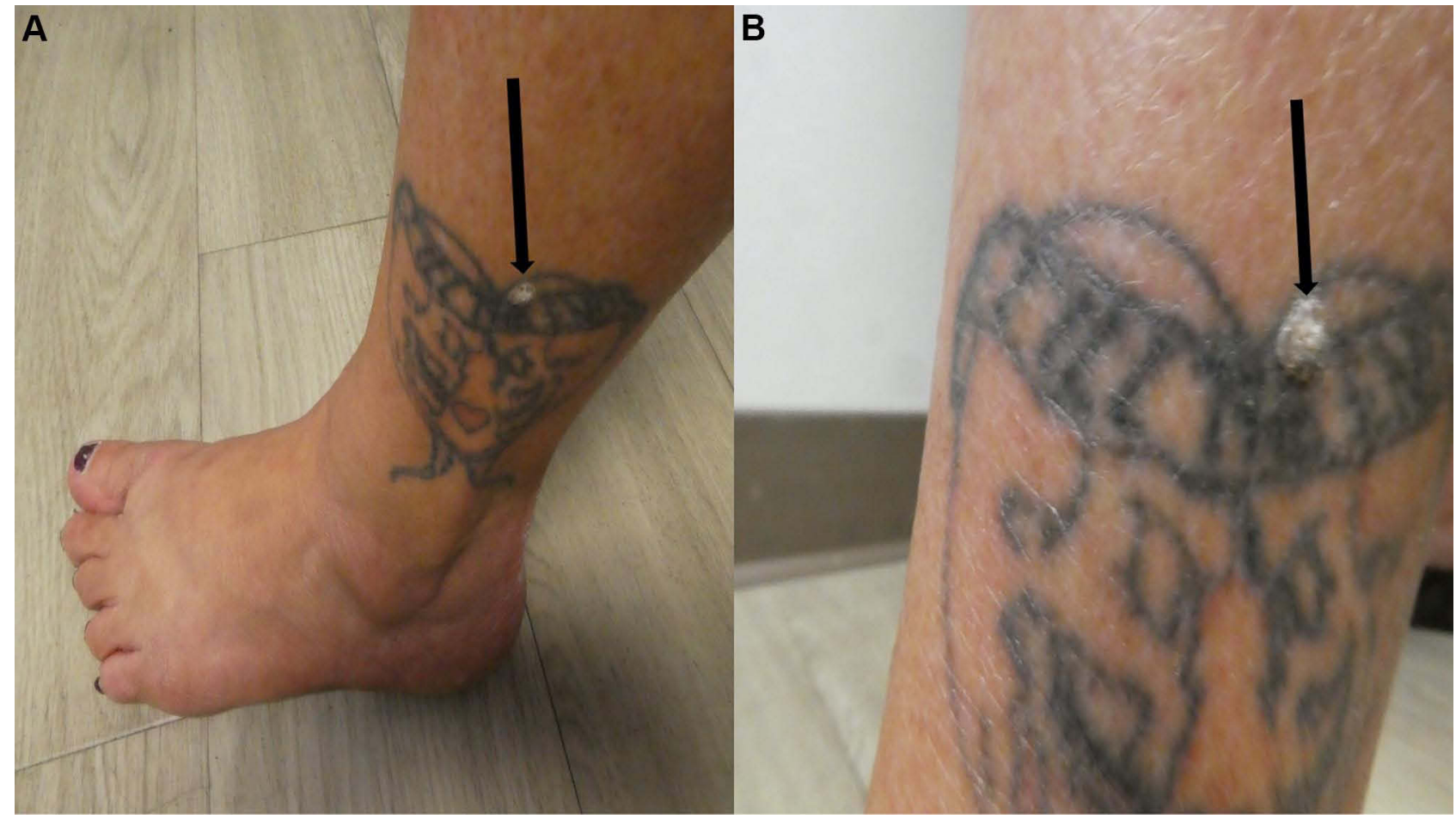

Figure I Tattoo-associated human papillomavirus infection. Distant (A) and closer (B) views of the left ankle of a 44-year-old woman show a verruca vulgaris (black arrow) that has developed on the black inked tattoo. She received her tattoo when she was 18 years old; the asymptomatic wart that developed within her tattoo appeared five years ago-26 years after tattoo inoculation-and subsequently increased in size. The patient's tattoo-associated verruca vulgaris has been reported. ${ }^{15}$ 
Table 4 Tattoo-Associated Human Papillomavirus Infections

\begin{tabular}{|c|c|c|c|}
\hline Feature & $\begin{array}{l}\text { Acquired Epidermodysplasia } \\
\text { Verruciformis }\end{array}$ & Verruca Plana & Verruca Vulgaris \\
\hline $\begin{array}{l}\text { Number of cases } \\
\text { Onset age (years): range (median) }\end{array}$ & $\begin{array}{l}2 \\
29-44(37)\end{array}$ & $\begin{array}{l}14 \\
20-48(30)\end{array}$ & $\begin{array}{l}29^{\mathrm{a}} \\
17-66(28)\end{array}$ \\
\hline $\begin{array}{l}\text { Number of men } \\
\text { Onset age (years): range (median) }\end{array}$ & $\begin{array}{l}2 \\
29-44(37)\end{array}$ & $\begin{array}{l}5 \\
20-48,(33)\end{array}$ & $\begin{array}{l}14 \\
18-39(35)\end{array}$ \\
\hline $\begin{array}{l}\text { Number of women } \\
\text { Onset age (years): range (median) }\end{array}$ & 0 & $\begin{array}{l}3 \\
21-39(27)\end{array}$ & $\begin{array}{l}4 \\
17-66(38)\end{array}$ \\
\hline $\begin{array}{l}\text { Tattoo artist: } \\
\text { professional/amateur }\end{array}$ & $2 / 0$ & $5 / 2$ & $15 / 2^{\mathrm{b}}$ \\
\hline $\begin{array}{l}\text { Tattoo duration }{ }^{c} \text { (months): } \\
\text { range (median) }\end{array}$ & Not stated & $6-234(24)^{c}$ & $1-252(21)^{c}$ \\
\hline Number of lesions & Multiple & Multiple $^{d}$ & Multiple $^{e}$ \\
\hline Tattoo location (number of patients) & $\begin{array}{l}\text { Arm and forearm (I) } \\
\text { Back (I) }\end{array}$ & $\begin{array}{l}\text { Extremity (5) } \\
\text { Chest (I) } \\
\text { Eyebrow (1) }\end{array}$ & $\begin{array}{l}\text { Extremity }(12)^{f} \\
\text { Scapula (3) } \\
\text { Abdomen (I) } \\
\text { Eyebrows (I) }\end{array}$ \\
\hline Tattoo color (number of patients) & $\begin{array}{l}\text { Black and red (I) } \\
\text { Dark grey (I) }\end{array}$ & $\begin{array}{l}\text { Black (6) } \\
\text { Dark blue (I) }\end{array}$ & $\begin{array}{l}\text { Black (2I) } \\
\text { Blue (4) } \\
\text { Dark (2) } \\
\text { Green (2) } \\
\text { Red (2) } \\
\text { Grey (I) } \\
\text { Indigo (I) } \\
\text { Multicolored (I) }\end{array}$ \\
\hline $\begin{array}{l}\text { Biopsy for diagnosis (number of } \\
\text { patients) }\end{array}$ & $+(2)$ & $+(7)$ & $+15^{\mathrm{h}}$ \\
\hline $\begin{array}{l}\text { Successful treatments (number of } \\
\text { patients) }\end{array}$ & Photodynamic therapy $(I)^{i}$ & $\begin{array}{l}\text { Curettage }(I) \\
\text { LN2 for three sessions and } 5 \% \text { imiquimod } \\
\text { cream (I) }\end{array}$ & $\begin{array}{l}\text { LN2 }(2)^{\mathrm{j}} \\
\text { SADBE CI }(2)^{\mathrm{k}} \\
\text { Curettage }(1) \\
\text { Laser and } 5 \% \text { imiquimod } \\
\text { cream }(1)^{\prime}\end{array}$ \\
\hline
\end{tabular}

Notes: ${ }^{a}$ These include the 27 patients summarized in a recent review ${ }^{15}$ and two additional cases presented only as images: (I) the legend states "viral warts restricted to tattooed areas" from a figure demonstrating warts on the "FS*" tattoo attributed to dermatologist Dr. Sylvain Reberga from Toulouse, France ${ }^{14}$ and (2) the legends state "papilloma virus infection after tattooing" that shows warts on a tattoo and "Koebner phenomenon on the same arm" showing a linear arrangement of warts not associated with the tattoo. ${ }^{3}$ bThe status of the tattoo artist was not stated for one young man from England who had his tattoo applied by an Italian in Port Elizabeth (which has since been renamed Gqeberha) in South Africa. 'Tattoo duration is the number of months after tattoo placement that the wart appeared. The verruca plana appeared within two years after tattoo inoculation for $57 \%$ (four of seven) of the patients. The verruca vulgaris appeared within three years after tattoo acquisition for $70 \%$ ( 12 of 17 ) of the patients. ${ }^{\mathrm{d}}$ The number of verruca plana, when described, were: more than two, 120, 150, and 100's. 'The number of verruca vulgaris, when described, ranged from one to greater than 400 (median, 17). ${ }^{f}$ Four of the patients also had warts that were not associated with their tattoo previously (on the back, one patient) ${ }^{15}$ or concurrently: either on the same arm (one patient) ${ }^{5}$ or perianal or genital (two patients). ${ }^{15}$ g Five of the patients had warts on more than one tattoo color: black and blue, black and dark grey, black and green, dark (not otherwise specified) and red, and green and red. ${ }^{\text {h}}$ Three of the 15 patients also had dermoscopy evaluation of their warts. However, $44 \%$ ( 12 of 27) patients had their wart diagnosed clinically, based on the morphology of the lesion. 'Photodynamic therapy consisted of three hours of skin incubation with topical methyl aminolevulinate (MAL) followed by illuminating the epidermodysplasia verruciformis lesions using a red-light source (635 nanometers) from a light emitting diode (LED) with a fluence of 37 Joules $/ \mathrm{cm}^{2}$. Sessions were performed at three-week intervals; after three sessions all of the viral lesions had completely resolved and had not recur at followup two years later. 'Cryotherapy, using liquid nitrogen, resulted in ablation of most or all the warts; however, mild distortion of the tattoo and/or post-treatment hypopigmentation occurred. " $\mathrm{SADBE}$ contact immunotherapy involves sensitization (by applying 100 microliter of $2 \%$ SADBE to 10 -centimeters ${ }^{2}$ area of the volar aspect of the uninvolved arm for 48 hours) and weekly treatment (by applying 100 microliters of $0.01 \%$ SADBE directly on the warts) beginning two weeks later. All of the verruca vulgaris resolved after eight or 10 weeks of treatment; there was no scar, no pigmentary alteration, and no recurrence of the viral lesions during a follow-up period of 10 months. 'Ablative erbium:yttrium aluminum garnet (YAG) laser treatment (one session) resulted in $80 \%$ resolution of the wart; the residual lesion resolved after 12 weeks of daily $5 \%$ imiquimod cream application.

Abbreviations: $\mathrm{Cl}$, contact immunotherapy; LN2, liquid nitrogen cryotherapy; SADBE, squaric acid dibutylester; +, positive or present; \%, percent. 
infection, but also for other viral infections (hepatitis B and hepatitis C) and syphilis; none of these individuals demonstrated any of these additional infections. ${ }^{15}$

All but four of the tattoos were performed by professional tattooists; in addition, one Englishman's tattoo was inoculated by an Italian when he was in South Africa. The technique of the amateur tattoo artist may have been a factor in the acquisition of the patient's tattooassociated HPV infection. For example, one artist used a staple to inoculate a mixture of ball point pen ink and melted plastic; however, prior to creating the tattoo, he used his saliva to thin the material used for pigment. ${ }^{15}$

Four patients had additional evaluation (such as in situ hybridization, polymerase chain reaction and/or deoxyribonucleic acid sequencing) to identify the HPV type associated with their infection. One woman with tattooassociated verruca vulgaris had HPV type 27 detected. Two men with tattoo-associated verruca plana had either HPV type 6B or HPV type 47. However, a positive reaction for HPV could not be demonstrated for one man with tattoo-associated verruca vulgaris. ${ }^{15}$

The tattoo duration prior to the onset of the HPV lesion ranged from 6 months to more than 19.5 years (median, 2 years) in patients with verruca plana and from 1 month to 21 years (median, 21 months) in patients with verruca vulgaris. However, the tattoo-associated HPV lesions appeared within either 2 years $(57 \%$ of the seven patients with verruca plana) or 3 years $(70 \%$ of the 17 patients with verruca vulgaris) after inoculation of the tattoo. Yet, in some individuals, prolonged duration between tattoo acquisition and the development of the associated HPV lesion was observed: $43 \%$ after 10 or more years for patients with verruca plana and either $24 \%$ between 5 and 8 years and $6 \%$ after 21 years for patients with verruca vulgaris. $^{15}$

The number of viral lesions varied from 1 to $100 \mathrm{~s}$; many of the reports used descriptive terms such as multiple or numerous or countless. The warts were most frequently located on an extremity (18 patients); other sites included the back (four patients), eyebrow (two patients), and one patient on either the chest or the abdomen. Previous (one woman with a wart on her back) or concurrent warts (condyloma in either the genital or perianal area of two men and linearly distributed warts on the ipsilateral arm of one patient), not associated with the tattoo, were noted in four individuals. ${ }^{15}$

The tattoo-associated HPV lesion was in a dark-inked area of the tattoo in both patients with HIV-associated epidermodysplasia verruciformis and seven patients with verruca plana; one of the HIV-positive men also had wart in the red inked area of his tattoo. The wart was also in the dark-colored portion of the tattoo in all 29 patients with verruca vulgaris; in 24 of these patients, the wart was only found in one tattoo color whereas the viral lesion appeared in more than one tattoo color in five patients. It has been suggested that the black ink has caused the development of a cutaneous immunocompromised district that more readily enables the development of HPV lesions in that skin area. $^{3,14,15}$

The diagnosis of tattoo-associated HPV lesions was based on the clinical impression in 33\% (12 of 36) patients. Biopsy-confirmation of a suspected wart was performed in the remaining $67 \%$ of individuals. Three of the patients with verruca vulgaris also had dermoscopic evaluation of their lesions, prior to microscopic evaluation of a lesion biopsy. ${ }^{15}$

Successful treatment of warts on tattoos was only observed in seven patients; however, some of the individuals declined additional therapy after the diagnosis had been established. Curettage was effective in a man with verruca plana and a woman with verruca vulgaris. Cryotherapy with liquid nitrogen was useful either as a single modality (in two men with verruca vulgaris) or as a precursor to topical 5\% imiquimod cream (one woman with verruca plana); however, both men experienced post-treatment hypopigmentation and one man noted mild distortion of his tattoo. In addition, monotherapy with liquid nitrogen resulted in no improvement for two men-one with HIV-associated epidermodysplasia verruciformis and one with verruca plana. ${ }^{15}$

Two men with verruca vulgaris were successfully treated, after eight or 10 weeks, with squaric acid dibutylester contact immunotherapy. One man with HIV-associated epidermodysplasia verruciformis had a complete resolution of his viral lesions after three sessions. And, one man with verruca vulgaris had a combination therapy consisting of ablative erbium:yttrium aluminum garnet (YAG) laser treatment (with $80 \%$ wart resolution after one session) followed by topical immunotherapy (with daily $5 \%$ imiquimod cream for 12 weeks). ${ }^{15}$

Several hypotheses have been proposed to account for the development of tattoo-associated HPV lesions. In addition to black (or dark) ink, tattoo inoculation-related trauma can also potentially contribute to the development of a cutaneous immunocompromised district and subsequent HPV infection at that skin site. However, viral 
contamination of either the instruments or pigment or both used by the tattooist during tattoo inoculation is the most likely etiology for pathogen introduction at the site of the tattoo. Also, the tattoo artist may be the source of HPV infection-either a wart-containing ungloved hand or viruscontaining saliva being used to thin the pigment to the appropriate consistency. Other possibilities include inoculation-related traumatic spread of an unrecognized preexisting wart at the site of tattoo inoculation or subsequent spread of HPV from currently existing or previous warts at different locations than where the tattoo is created. ${ }^{15}$

\section{Molluscum Contagiosum}

Molluscum contagiosum, a poxvirus-associated infection, clinically presents as umbilicated papules. It is frequently observed in children and may be located on the antecubital and popliteal fossa, the axilla, and the trunk. However, in adult patients, it may be a sexually transmitted diseaseparticularly when the lesion is in the genital region. ${ }^{19,23}$

Tattoo-related molluscum contagiosum has been observed (Table 5). ${ }^{16-29}$ Characteristics of these individuals have been provided for 11 of the patients: one woman and 10 men. The individuals were most frequently from Spain (five patients) and Italy (three patients); one patient was from either Brazil, England, or France.

The woman was 20 years old. The men ranged in age from 20 years to 59 years (median, 27 years). Ninety percent of the men were 36 years old or younger.

Ten of the tattoos were professionally done. However, for one individual, the patient's friend-without protective measures-performed his tattoo. Subsequently, 3 months later, the 33-year-old Spanish man presented with several pruritic molluscum contagiosum located on the inked lines of the tattoo on his right arm. ${ }^{24}$

The molluscum contagiosum appeared two to 24 weeks (median, 12 weeks) after the tattoo was performed. When specified, the number of lesions ranged from 10 to 50 lesions (median, 20 lesions). However, the lesion number was most frequently described as several (seven patients); for one patient, the lesion number was described as many.

The diagnosis of molluscum contagiosum was confirmed by microscopic examination of a tissue specimen of the lesion for seven patients. The diagnosis was established based on clinical morphology of the lesions for four patients. Dermoscopy was performed for one patient-a 24year-old man who, 2 weeks after receiving a tattoo of a lion on his right lumbar region-developed several asymptomatic popular lesions; examination of each individual lesion revealed a small whitish discoid area in the center of a round white shiny lesion. ${ }^{21}$

The most common locations of the molluscum contagiosum-containing tattoo were the upper extremity (six patients: arm, three patients; upper arm, two patients; and forearm, one patient) and the torso (three patients: back, two patients; and abdomen, one patient). Less often, each site in only one patient, the tattoo with its associated molluscum contagiosum was on the calf or chest. In all the individuals, viral lesions were not found at any other site.

The tattoo pigment color in which the molluscum contagiosum developed was black for 10 of the patients. A 33year-old Spanish man with a multi-colored tattoo developed molluscum contagiosum not only in the areas of black ink but also in locations inked in either blue or red. $^{23}$ A 20-year-old Spanish man with a multi-colored tattoo only had molluscum contagiosum over the browngrey tattoo background; lesions did not occur on either black-inked picture lines or the other colors that were used to fill in the tattoo. ${ }^{18}$

All the patients were immunocompetent. Eight of the patients were also evaluation for other sexually transmitted diseases that could also be transmitted by tattooing. Hepatitis B (eight patients), hepatitis C (nine patients), HIV (nine patients), and syphilis (seven patients) were absent in all these individuals.

Management of the molluscum contagiosum was described in nine of the patients. Curettage of the viral lesions-either once (four patients) or on multiple occasions (two patients) was performed for six patients; there was no recurrence observed at follow-up of two of these individuals. $^{20,25}$ Three patients did not receive any treatment; two of the individuals refused therapy ${ }^{16,26}$ and the lesions resolved spontaneously within 6 months in a 20year-old English man who had several molluscum contagiosum on his left upper arm tattoo. ${ }^{17}$

Two potential mechanisms of pathogenesis were postulated for the development of tattoo-associated molluscum contagiosum. The first hypothesis for the transmission of poxvirus involves exposure to a contaminated fomiteparticularly the instruments (needles) used for tattooing. ${ }^{16,18,19,22,23}$ The second theory is that either the tattoo ink or the water used to dilute the ink contained poxvirus. ${ }^{16-19,23}$ Some of the investigators have also suggested that the black pigment in the ink created a cutaneous immunocompromised district by promoting a reduction of cellular immunity or humoral immunity or 
Table 5 Tattoo-Associated Molluscum Contagiosum Virus Infection

\begin{tabular}{|c|c|c|c|c|c|c|c|c|c|}
\hline$C^{a}$ & $\begin{array}{l}\mathrm{A} \\
\mathrm{Na} \\
\mathbf{G}\end{array}$ & $\begin{array}{l}\text { TD } \\
\text { PT }\end{array}$ & NOL & Bx & Site & $\begin{array}{l}\text { Tattoo } \\
\text { Color }\end{array}$ & $\begin{array}{l}\text { IC } \\
\text { HB, HC } \\
\text { HIV, Sy }\end{array}$ & Txment & Ref \\
\hline 1 & $\begin{array}{l}20 \\
\text { It } \\
W\end{array}$ & $\begin{array}{l}3 \\
+\end{array}$ & 10 & + & $\begin{array}{l}\text { Left } \\
\text { Forearm }\end{array}$ & Black & $\begin{array}{l}+ \\
-,- \\
-,-\end{array}$ & $\begin{array}{l}\text { None } \\
\text { (patient } \\
\text { refused) }\end{array}$ & [16] \\
\hline 2 & $\begin{array}{l}20 \\
\text { En } \\
M\end{array}$ & $\begin{array}{l}12 \\
+\end{array}$ & Sev & + & $\begin{array}{l}\text { Left } \\
\text { Upper } \\
\text { Arm }\end{array}$ & Black $^{\mathrm{b}}$ & $\begin{array}{l}+ \\
\text { NS, NS } \\
\text { NS, NS }\end{array}$ & $\begin{array}{l}\text { None (resol } \\
\text { spont within } 6 \text { months) }\end{array}$ & [17] \\
\hline 3 & $\begin{array}{l}20 \\
S p \\
M\end{array}$ & $\begin{array}{l}20^{c} \\
+\end{array}$ & Sev & + & $\begin{array}{l}\text { Left } \\
\text { Calf }\end{array}$ & $\begin{array}{l}\text { Brown- } \\
\text { Grey }^{d}\end{array}$ & $\begin{array}{l}+ \\
-,- \\
-,-\end{array}$ & NS & [18] \\
\hline 4 & $\begin{array}{l}22 \\
\mathrm{Bz} \\
\mathrm{M}\end{array}$ & $\begin{array}{l}20^{\mathrm{e}} \\
+\end{array}$ & 50 & + & Back & Black & $\begin{array}{l}+ \\
-,- \\
-,-\end{array}$ & Curettage & [19] \\
\hline 5 & $\begin{array}{l}23 \\
S p \\
M\end{array}$ & $\begin{array}{l}\text { NS } \\
+\end{array}$ & Sev & + & $\begin{array}{l}\text { Right } \\
\text { Abdom } \\
\text { Flank }\end{array}$ & Black & $\begin{array}{l}+ \\
-,- \\
-,-\end{array}$ & $\begin{array}{l}\text { Curettage } \\
\text { (mult sess) } \\
\text { Not recur }\end{array}$ & [20] \\
\hline 6 & $\begin{array}{l}24 \\
\text { It } \\
M\end{array}$ & $\begin{array}{l}2 \\
+\end{array}$ & Sev & $\begin{array}{l}-\mathrm{CD} \\
\mathrm{Dm}\end{array}$ & $\begin{array}{l}\text { Right } \\
\text { Lumbar }\end{array}$ & Black & $\begin{array}{l}+ \\
\text { NS, NS } \\
\text { NS, NS }\end{array}$ & Curettage & [21] \\
\hline 7 & $\begin{array}{l}30 \\
\text { It } \\
M\end{array}$ & $\begin{array}{l}3 \\
+\end{array}$ & Mny & + & Arm & Black & $\begin{array}{l}+ \\
-,- \\
-,-\end{array}$ & $\begin{array}{l}\text { Curettage } \\
\text { (mult sess) }\end{array}$ & [22] \\
\hline 8 & $\begin{array}{l}33 \\
S p \\
M\end{array}$ & $\begin{array}{l}20 \\
+\end{array}$ & Sev & $-C D$ & $\begin{array}{l}\text { Right } \\
\text { Upper } \\
\text { Arm }\end{array}$ & $\begin{array}{l}\text { Black } \\
\text { Blue } \\
\text { Red }\end{array}$ & $\begin{array}{l}+ \\
-,- \\
-,-\end{array}$ & NS & [23] \\
\hline 9 & $\begin{array}{l}33 \\
S p \\
M\end{array}$ & $12-$ & $\operatorname{Sev}^{f}$ & $-C D$ & Right Arm & Black & $\begin{array}{l}+ \\
-,- \\
-,-\end{array}$ & Curettage & [24] \\
\hline 10 & $\begin{array}{l}36 \\
S p \\
M\end{array}$ & $\begin{array}{l}3^{g} \\
+\end{array}$ & Sev & + & $\begin{array}{l}\text { Right } \\
\text { Arm }\end{array}$ & Black & $\begin{array}{l}+ \\
-,- \\
-, \text { NS }\end{array}$ & $\begin{array}{l}\text { Curettage } \\
\text { Not recur }\end{array}$ & [25] \\
\hline 11 & $\begin{array}{l}59 \\
\mathrm{Fr} \\
\mathrm{M}\end{array}$ & $\begin{array}{l}24 \\
+\end{array}$ & 20 & $-C D$ & Chest & Black & $\begin{array}{l}+ \\
\text { NS, - } \\
-, \text { NS }\end{array}$ & $\begin{array}{l}\text { None } \\
\text { (patient } \\
\text { refused) }\end{array}$ & [26] \\
\hline
\end{tabular}

Notes: ${ }^{\mathrm{C} C}$ ase 12 is the initial description of molluscum contagiosum included in a tattoo; it is discussed in an article by Dr. J. Ullmann that was written in German and published in 1903 in Monatshefte fur Praktische Dermatologie titled "About peculiar tumor formation in a tattoo mark". ${ }^{27}$ The paper credits the observation of Dr. Bergh but does not provide specific details regarding the patient: "Professor Bergh in Copenhagen, as I received a written letter from him, also saw acne varioliformis and molluscum contagiosum included in the process, while he is not aware of the changes I have described below. The tattoo can therefore, under certain circumstances, have been unfortunate for the individual provided with the colorful jewelry". Unfortunately, both Perez-Barrio et $\mathrm{a}^{25}$ and Panasiti et $\mathrm{al}^{2 \mathrm{I}}$ erroneously cited Dr. Bergh as the author of this paper. Case 13 is contributed by Drs. Kiang and Bang; ${ }^{28}$ the investigators published an abstract about infectious diseases arising in new tattoos. Specifically, they commented that "Infectious diseases arising within tattoos occur rarely .... We present two interesting cases of infectious diseases complicating new tattoos. The first patient developed a collection of papules within a recently colored tattoo. Biopsy of a papule was consistent with molluscum contagiosum .... These cases highlight the potential health risks posed by this popular form of body art. Unfortunately, Perez-Barrio et al ${ }^{25}$ incorrectly cited the paper in the reference section of their article. Case 14 is a clinical image included in a review article by Kluger. ${ }^{29}$ The image, titled "Molluscum contagiosum on a tattoo" was

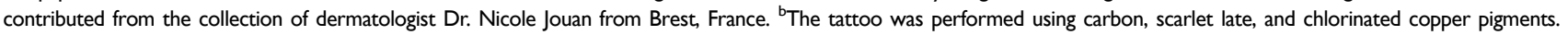
Molluscum contagiosum only appeared in the black pigment which consisted of charcoal suspended in ammoniacal solution containing phenol. 'The tattoo was done in three sessions (at two-week intervals): (I) black ink used to draw the picture lines, (2) brownish-grey pigment for background of the drawing, and (3) other colors to fill in the figure ${ }^{\mathrm{d}}$ Molluscum contagiosum only occurred in the brownish-grey ink of the picture base. It was neither in the picture lines (black ink) or pigment filling the figure (other colors). ${ }^{\mathrm{e}}$ The tattoo was done in various sessions within a total period of four months. ${ }^{f}$ The molluscum contagiosum presented as pruritic lesions. ${ }^{g}$ There was progressive loss of pigment from the original tattoo that had been performed several years earlier with no associated problems; the molluscum contagiosum appeared three weeks after a recoloring procedure had been done.

Abbreviations: A, age (years); Abdom, abdominal; Bx, biopsy confirmation of molluscum contagiosum diagnosis; Bz, Brazilian; C, case; CD, clinical diagnosis; DM, dermoscopy; En, English; Fr, French; G, gender; HB, hepatitis B virus; HC, hepatitis C virus; HIV, human immunodeficiency virus; IC, immunocompetent; It, Italian; M, man; Mny, many; Na, nationality; NOL, number of lesions; NS, not stated; PT, professional tattoo; Ref, reference; Resol, resolved; Sess, sessions; Sev, several; Sp, Spanish; Spont, spontaneously; Sy, syphilis; TD, tattoo duration (number of weeks after tattoo placement that molluscum contagiosum lesion appeared); Txment, treatment; W, Woman, +, positive; -, negative. 
both and enabling the development of molluscum contagiosum within the black-inked areas of the tattoo. ${ }^{16,24}$

\section{Rubella (German Measles) Virus}

Rubella, also known as German measles, is a viral infection that presents with a maculopapular rash on the face and subsequently spreads to the trunk and extremities; accompanying symptoms include fever, lymphadenopathy, headaches, arthralgias, and conjunctivitis. Currently, the mumps, measles and rubella (MMR) vaccine has interrupted the transmission of rubella. However, prior to vaccination, rubella lesions were observed not only in tattoos but also on the remainder of the skin; indeed, in 1979, Dr. Goldstein published an image provided by R. G. Davis, MD of rubella in a tattooed lady. ${ }^{30}$

\section{Vaccinia (Smallpox) Virus}

A bifurcated needle containing vaccine is used to repeatedly traumatize the skin to deliver vaccinia smallpox vaccine. Once inoculated, the live virus replicates in the dermis and-within 2 to 5 days-a small papule appears that progresses into a vesicle and then a pustule (which designates that the vaccine has successfully taken) during a total period of 8 to 10 days. Eventually, a scab develops at the pustule site, which subsequently detaches, leaving a residual scar. ${ }^{31}$

Tattoo-associated vaccinia (smallpox) autoinoculation has been reported in two men (Table 6). ${ }^{31,32}$ The first report, published in 1930 by Dr. Wilde, included vivid descriptions not only of the soldier's recently acquired tattoo but also of the reaction to the smallpox vaccination that was inoculated near the tattoo's upper edge. ${ }^{32}$ The more recently published paper in 2019 describes a soldier who, 4 days after vaccination, received a "touch up" directly over his inoculation site of a previous tattoo and experienced smallpox autoinoculation. ${ }^{31}$

In addition, from 2003 to 2018, the Vaccine Adverse Events Reporting System (VAERS) database was search using the following terms: smallpox, tattoo and vaccinia. Thirteen cases associated with tattoo and smallpox inoculation complications were discovered. The tattoo was placed either directly over or adjacent to the vaccinia inoculation site within 96 hours following vaccine administration in six cases; however, reactions occurred up to 3 years post-inoculation. When described, the reactions included bumps and pustules; one person was febrile. ${ }^{31}$

The investigators postulate that both the tattoo and the vaccine create a cutaneous immunocompromised district

Table 6 Tattoo-Associated Vaccinia (Smallpox) Autoinoculation

\begin{tabular}{|c|c|c|c|}
\hline C & $\begin{array}{l}\text { Age } \\
\text { Race } \\
\text { Sex }\end{array}$ & Comments & Ref \\
\hline I & $\begin{array}{l}21 y \\
\text { AA } \\
\text { Man }\end{array}$ & $\begin{array}{l}\text { A large tattoo-whose duration was not stated-had been present on the soldier's left shoulder. Four days after receiving } \\
\text { smallpox vaccine inoculation within the tattoo located on his left deltoid, he had a touch up of the tattoo which included the } \\
\text { area directly over the inoculation site. Soon after receiving the tattoo touch up, his entire left shoulder became pruritic and } \\
\text { he developed many bumps within and around both the newly added and previously existing tattoo. Subsequently, the flesh- } \\
\text { colored, less than 2-millimeter, papules (and vesicle at the inoculation site) became umbilicated, crusted, and exudative with } \\
\text { a yellow discharge; he also experienced fever and increased pain of his erythematous left shoulder. He was empirically treated } \\
\text { with trimethoprim-sulfamethoxazole for a suspected MRSA infection; within two days, the erythema resolved, he was } \\
\text { afebrile, and the previous lesions on his pain-free left shoulder had scabbed. The affected area healed within } 23 \text { days after } \\
\text { tattoo touch up (and } 27 \text { days after vaccine inoculation) with hypopigmented scarring. }\end{array}$ & [3I] \\
\hline 2 & $\begin{array}{l}23 y \\
\text { NS } \\
\text { Man }\end{array}$ & $\begin{array}{l}\text { The soldier's left upper arm received a tattoo that " ... consisted of a scantily bedecked, but liberally bepainted female, } \\
\text { enwreathed in dice, cards, guns, knives, and bottles, the whole bearing the caption Man's Ruin." His upper arm subsequently } \\
\text { became tender and swollen; this reaction resolved within three weeks and he was vaccinated near the upper edge of the } \\
\text { tattoo. Blisters developed in the area of the tattoo adjacent to the vaccination site after three days. The blisters spread "... } \\
\text { rapidly until both the lady and her halo were completely submerged beneath a flood of vesication, and reduced to an } \\
\text { indistinguishable blob." Thereafter, " ... the customary phases of an orthodox vaccination [occurred], although on a scale } \\
\text { usually associated only with the calf in the laboratory." A five by eight centimeter quadrilateral area of "... dark brown, } \\
\text { adherent and deeply wrinkled crust, resembling that which forms on a can of derived varnish ... " developed and " ... during } \\
\text { the second week this peeled off almost whole, leaving a thin pink cicatrix beneath, but both the lady and her satellites were } \\
\text { found to have passed into history." }\end{array}$ & [32] \\
\hline
\end{tabular}

Abbreviations: AA, African American; C, case; MRSA, methicillin-resistant Staphylococcus aureus; NS, not stated; Ref, reference; y, years. 
of local immune dysregulation that is prone to the development of skin adverse events or cutaneous conditions in the affected area. Hence, the Assistant Secretary of Defense for Health Affairs (ASDHA) advised that tattooed skin not be selected as a vaccination site; subsequently, the United States Army Public Health Command (USAPHC) clarified this recommendation with regard to vaccinia administration: new tattoos should not be acquired until the vaccination site is healed and receiving tattoos within 30 days or less of vaccinia vaccination was contraindicated. Thereafter, the Military Vaccine Agency extended the period from vaccination to tattoo acquisition to 60 days. $^{31}$

\section{Conclusion}

Tattoo-associated viral infections have been caused by pathogens that predominantly present with either cutaneous lesions (HSV infection, HPV, molluscum contagiosum, rubella, and vaccinia) or systemic manifestations (hepatitis B, hepatitis C, and HIV). HPV lesions in 45 patients (predominantly verruca vulgaris and verruca plana and less often acquired epidermodysplasia verruciformis) and molluscum contagiosum in 14 patients are the most observed viral lesions occurring on tattoos. Nearly all the patients were immunocompetent; however, both men who developed acquired epidermodysplasia verruciformis were HIV-positive. Herpes compunctorum (tattoo-associated HSV infection) has only been described in three patients; similarly, viral infections of tattoos caused by rubella (one patient) and vaccinia (two patients) were rare. The observation of individuals with newly acquired tattoo-associated rubella is unlikely based upon current medical practice of routine childhood vaccination for rubella. Likewise, new patients with tattoo-associated vaccinia are not anticipated since the use of smallpox vaccination has been significantly diminished. The potential to acquire blood-borne viral pathogens such as hepatitis B, hepatitis C and HIV during tattooing still exists; however, health care interventions to prevent transmission of these viral agents during the acquisition of a tattoo may be helpful in reducing the development of the virus-associated diseases in these individuals.

\section{Disclosure}

Dr. Philip R Cohen reports he is a consultant for ParaPRO. However, this relationship has no financial conflict of interest regarding the current paper.

\section{References}

1. Islam PS, Chang C, Selmi C, et al. Medical complications of tattoos: a comprehensive review. Clin Rev Allergy Immunol. 2016;50 (2):273-286. doi:10.1007/s12016-016-8532-0

2. Cohen PR, Erickson CP, Uebelhoer NS, Calame A. Tattoo-associated basal cell carcinoma: coincident or coincidence. Biomed Hub. 2020;5 (2):2055-2062. doi:10.1159/000508208

3. Kazandjieva J, Tsankov N. Tattoos: dermatological complications. Clin Dermatol. 2007;25(4):375-382. doi:10.1016/j.clindermatol.2007.05.012

4. Messahel A, Musgrove B. Infective complications of tattooing and skin piercing. J Infect Public Health. 2009;2(1):7-13. doi:10.1016/j. jiph.2009.01.006

5. Jafari S, Buxton JA, Afshar K, Copes R, Bahariou S. Tattooing and risk of hepatitis B: a systematic review and meta-analysis. Can J Public Health. 2012;103(3):207-212. doi:10.1007/BF03403814

6. Nishioka SDA, Gyorkos TW, Joseph L, Collet JP, Maclean JD. Tattooing and risk for transfusion-transmitted diseases: the role of the type, number and design of the tattoos, and the conditions in which they were performed. Epidemiol Infect. 2002;128(1):63-71. doi:10.1017/S0950268801006094

7. Tohme RA, Holmberg SD. Transmission of hepatitis C virus infection through tattooing and piercing: a critical review. Clin Infect Dis. 2012;54(8):1167-1178. doi:10.1093/cid/cir991

8. Jafari S, Copes R, Baharlou S, Etminan M, Buxton J. Tattooing and the risk of transmission of hepatitis $\mathrm{C}$ : a systematic review and meta-analysis. Int $J$ Infect Dis. 2010;14(11):e928-e940. doi:10.1016/j.ijid.2010.03.019

9. Marshall CS, Murphy F, McCarthy SE, Cheng AC. Herpes compunctorum: cutaneous herpes simplex virus infection complicating tattooing. Med J Aust. 2007;187(10):598. doi:10.5694/j.1326-5377.2007.tb01435.x

10. Kluger N, Armingaud P. Herpes simplex infection on a recent tattoo. A new case of "herpes compunctorum". Int J Dermatol. 2017;56(1): e9-e10. doi:10.1111/ijd.13388

11. Gerqari AB, Ferizi M, Kotori M, et al. Activation of herpes simplex infection after tattoo. Acta Dermatovenerol Croat. 2018;26(1):75-76.

12. Doll D. Tattooing in prison and HIV infection. Lancet. 1988;1(85758576):66-67. doi:10.1016/S0140-6736(88)91054-9

13. Garland SM, Ung L, Vujovic OV, Said JM. Cosmetic tattooing: a potential transmission route for HIV? Aust N Z J Obstet Gynaecol. 2006;46(5):458-459. doi:10.1111/j.1479-828X.2006.00635.x

14. Kluger N. Cutaneous and systemic complications associated with tattooing. Presse Med. 2016;45(6Pt1):567-576. doi:10.1016/j. lpm.2016.02.016

15. Cohen PR. Verruca vulgaris occurring on a tattoo: case report and review of tattoo-associated human papillomavirus infections. Cureus. 2021;13(8):e17575.

16. Salmaso F, Gnecchi L, Gianotti R, Verladi S. Molluscum contagiosum on a tattoo. Acta Derm Venereol. 2001;81(2):146-147. doi:10.1080/00015550152384362

17. Foulds IS. Molluscum contagiosum: an unusual complication of tattooing. $\mathrm{Br}$ Med $J$ (Clin Res Ed). 1982;285(6342):607. doi:10.1136/bmj.285.6342.607

18. Perez Gala S, Alonso Perez A, Rios Buceta L, Aragues Montanes M, Garcia Diez A. Molluscum contagiosum on a multicoloured tattoo. J Eur Acad Dermatol Venereol. 2006;20(2):221-222. doi:10.1111/ j.1468-3083.2005.01363.x

19. Molina L, Romiti R. Molluscum contagiosum on tattoo. An Bras Dermatol. 2011;86(2):352-354. doi:10.1590/S036505962011000200022

20. Ruiz-Villaverde R, Sanchez-Cano D. Pearled papules over tattoo: molluscum contagiosum. Pan Aft Med J. 2013;16:49.

21. Panasiti V, Devirgiliis V, Roberti V, Curzio M, Calvieri S. Molluscum contagiosum on a tattoo: usefulness of dermoscopy. Int J Dermatol. 2008;47(12):1318-1319. doi:10.1111/j.1365-4632.2008.03747.x 
22. De Giorgi V, Grazzini M, Lotti T. A three-dimensional tattoo: molluscum contagiosum. CMAJ. 2010;182(9):E382. doi:10.1503/cmaj.091480

23. Grillo E, Urech M, Vano-Galvan S, Jaen P. Lesions on tattooed skina case study. Aust Fam Physician. 2012;41(5):308-309.

24. Blasco-Morente G, Naranjo-Diaz MJ, Perez-Lopez I, MartinezLopez A, Garrido-Colmenero C. Molluscum contagiosum over tattooed skin. Sultan Qaboos Univ Med J. 2016;16(2):e257-e258. doi:10.18295/squmj.2016.16.02.022

25. Perez-Barrio S, Gonzalez-Hermosa MR, Raton JA, Diaz-Perez JL. Molluscum contagiosum over a tattoo. Actas Dermosifiliogr. 2009;100(2):152-154

26. Kluger N, Comte C, Guillot B. Molluscum contagiosum on a tattoo. Ann Dermatol Venereol. 2007;134(5 Pt 1):506-507. doi:10.1016/ S0151-9638(07)89231-3

27. Ullmann J. About peculiar tumor formation in a tattoo mark. Monatshefte Fur Praktische Dermatologie. 1903;37(2):49-52.

28. Kiang S-H, Bang RH. Infectious diseases arising in new tattoos: molluscum contagiosum and methicillin-resistant Staphylococcus aureus [P2011-Abstract at Poster Session]. J Am Acad Dermatol. 2006;54(3, Suppl. AB):AB155.
29. Kluger N. Cutaneous infections related to permanent tattooing. Med Mal Infect. 2011;41(3):115-122. doi:10.1016/j.medmal.2010. 09.013

30. Goldstein N IV. Complications from tattoos. J Dermatol Surg Oncol. 1979;5(11):869-878. doi:10.1111/j.1524-4725.1979.tb00770.x

31. Carius BM, Dodge PM, Randles JD. Smallpox autoinoculation via tattoo in a soldier. Mil Med. 2019;184(1-2):e275-e279. doi:10.1093/ milmed/usy180

32. Wilde AG. Vaccina infected tattoo. Case report. New Orleans Med Surg J. 1929-1930;82:385-386.

33. Fox TC. Warts occurring on tattooed lines. J Cutan Vener Dis. $1884 ; 2: 216$.

34. Walker HFB. Infective warts. Br Med J. 1908;2:1104.

35. Watkins DB. Viral disease in tattoos: verruca vulgaris. Arch Dermatol. 1961;84:306-309. doi:10.1001/archderm.1961.01580140132017

\section{Publish your work in this journal}

Clinical, Cosmetic and Investigational Dermatology is an international, peer-reviewed, open access, online journal that focuses on the latest clinical and experimental research in all aspects of skin disease and cosmetic interventions. This journal is indexed on CAS.
The manuscript management system is completely online and includes a very quick and fair peer-review system, which is all easy to use. Visit http://www.dovepress.com/testimonials.php to read real quotes from published authors. 